\title{
THE TIME COURSE OF OXYGEN UPTAKE, AEROBIC CAPACITY AND EMG DURING TWO MONTHS OF MODERATE INTERVAL ENDURANCE TRAINING (A CASE STUDY)
}

\author{
Sandra Raubaitė, Neringa Baranauskienė, Arvydas Stasiulis \\ Lithuanian Sports University, Kaunas, Lithuania
}

\begin{abstract}
Research background and hypothesis. The low-moderate-intensity continuous endurance training improved body composition, aerobic capacity and overall health-related parameters in healthy persons. However, we could not find publications about the effect of moderate interval aerobic endurance training (IET) on body composition, $\dot{\mathrm{V}} \mathrm{O}_{2}$ kinetics, aerobic capacity and EMG parameters.

Research aim. The main purpose of this study was to examine the effect of interval endurance training (IET) on oxygen uptake kinetics, aerobic capacity, body composition and EMG parameters.

Research methods. A 26-year-old, sedentary obese female (stature $-1.80 \mathrm{~m}$; weight $-99.2 \mathrm{~kg} ; \mathrm{VO}_{2} \max -$ $37.2 \mathrm{ml} / \mathrm{kg}^{-1} / \mathrm{min}^{-1}$ ) was involved in two-month moderate interval endurance training (IET). The subject performed three training sessions a week separated by one or two days of rest. The initial intensity of training was $90 \%$ of the first ventilation threshold (VT1). The VT1 and second ventilation threshold (VT2) ware estimated after completion of incremental running test until exhaustion on a LE 200 CE treadmill (VIASYS, Germany).

Research results. We determined that after two months IET subject' body mass decreased by $10 \%$, the training had an effect on aerobic capacity parameters as well. The running speed at VT1 and VT2 increased by $8.1 \%$ and $10.2 \%$ respectively after the two-month IET programme. The heart rate $\left(165.9\right.$ beats $\left./ \mathrm{min}^{-1}\right)$ and oxygen uptake $\left(2.583 \mathrm{l} / \mathrm{min}^{-1}\right)$ significantly decreased respectively $\left(150.4 \mathrm{beats} / \mathrm{min}^{-1}\right)\left(2.285 \mathrm{l} / \mathrm{min}^{-1}\right)$ after IET period compared with pre-training testing. To indicate the total muscle activity we measured integrated EMG (iEMG) and root mean square (RMS). We also determined changes on EMG parameters after four, six and eight weeks IET.

Discussion and conclusions. Two-month moderate interval endurance training has significant effect on aerobic capacity, anthropometrics, EMG parameters and $\mathrm{VO}_{2}$ kinetics.
\end{abstract}

Keywords: ventilatory thresholds, maximal oxygen uptake, EMG root mean square.

\section{INTRODUCTION}

I $\mathrm{t}$ is well established that low-to-moderateintensity continuous endurance training has been the most common type of exercise recommended to improve body composition, aerobic capacity and overall health-related parameters in healthy (Donnelly et al., 2009) and obese people (McInnis et al., 2003). Several studies showed that endurance and high intensity training induced similar metabolic, cardiorespiratory system and skeletal muscle molecular adaptations

in healthy humans (Burgomaster et al., 2008; Rakobowchuk et al., 2008) and in obese children (Corte et al., 2012). Also, M. J. Gibala et al. (2006) observed that two-week endurance training improved exercise performance and maximal activity. The oxygen uptake $\left(\mathrm{VO}_{2}\right)$ at the ventilatory thresholds and maximal oxygen uptake $\left(\mathrm{VO}_{2} \max \right)$ led to significant improvement after combined (consisting of continuous and interval load) endurance training (Carter et al., 2000). 
I. E. Schjerve et al. (2008) demonstrated that high intensity aerobic interval training had a higher effect on $\mathrm{VO}_{2}$ max than moderate intensity training.

Previous studies examining the effect of training on $\mathrm{VO}_{2}$ kinetics typically used a more "traditional" exercise training regime (i. e. continuous endurance exercise at - $60-65 \%$ $\mathrm{VO}_{2} \max$, for 30-120 min) (Philips et al., 1995; Carter et al., 2000). However, different training has various effects on $\mathrm{VO}_{2}$ kinetics. It was determined that endurance exercise training (4-6 wk.) had an effect on $\mathrm{VO}_{2}$ kinetics during the transition to moderate intensity exercise, a significant reduction in time constants for $\mathrm{VO}_{2}\left(\mathrm{tVO}_{2}\right)$ was reported after only 4 days of training (Phillips et al., 1995).

The $\mathrm{VO}_{2} \max , \mathrm{VO}_{2}$ kinetics parameters are related to electrical activity of skeletal muscles. The surface electromyography (EMG) signals such as amplitude (integrated EMG (iEMG), root mean square or (RMS)) and power spectrum (mean power frequency (MPF)) are commonly used to assess the level of muscle fatigue or changes in motor units during static and dynamic exercises (Farina et al., 2004). It is already known that the amplitude of iEMG increases and it means that fast-twitch fibres are gradually recruited during exhausting exercises and constant-load exercise (Shinohara, Moritani, 1992). It is likely that both type I and II fibres are recruited at the onset of exercise, and that as intense exercise progresses, a greater proportion of type II fibres are recruited as type I fibres become fatigued (Krustrup et al., 2004 b).

There are several studies which try to explain the effect of different training on aerobic capacity, $\mathrm{VO}_{2}$ kinetics. For the first time we are trying to explain the effect of moderate intensity interval training on cardiorespiratory system and EMG parameters in sedentary obese women. We hypothesized that a two-month interval endurance training would have a positive effect on body composition, $\mathrm{VO}_{2}$ kinetics, aerobic capacity and EMG parameters in sedentary obese subject. Therefore, the purpose of this study was to examine the effect of IET on body composition, oxygen uptake kinetics, aerobic capacity and EMG parameters.

\section{RESEARCH METHODS}

Participant. A 26-year-old untrained female (stature - $1.80 \mathrm{~m}$; weight $-99.1 \mathrm{~kg}$; $\mathrm{VO}_{2} \max -$ $37.2 \mathrm{ml} / \mathrm{kg}^{-1} / \mathrm{min}^{-1}$ ) was involved in 8 -week moderate interval endurance training (IET).
The experimental protocol was approved by the Lithuanian Ethics Committee of Kaunas University of Medicine (No. BE-2-68).

Training Programmes. The two-month IET session consisted of 8 repetitions of the following intervals: 4 min running of constant moderate intensity followed by 2 min walking (at $5 \mathrm{~km} / \mathrm{h}$ ) and 2 min rest periods. The participant performed 3 trainings sessions a week separated by $1-2$ days of rest. The intensity of IRT was $90 \%$ of the first ventilation threshold (VT1).

Incremental running test. The participant performed incremental running test (IRT) until exhaustion on a LE 200 CE treadmill (VIASYS, Germany). The subject was standing on the sides of treadmill 2 minutes till the speed increased to $7 \mathrm{~km} / \mathrm{h}^{-1}$, then she constantly ran for 4 minutes $\left(7 \mathrm{~km} / \mathrm{h}^{-1}\right)$, at the end of this period the load was increased incrementally $\left(0.1 \mathrm{~km} / \mathrm{h}^{-1}\right.$ per $\left.6 \mathrm{~s}\right)$ to maximum $20 \mathrm{~km} / \mathrm{h}^{-1}$ speed, then the slope was raised $(0.05 \%$ per $6 \mathrm{~s})$ until the subject stopped the treadmill due to fatigue.

Pulmonary gas exchange date collection. Pulmonary gas exchange parameters $\left(\mathrm{VO}_{2} ; \mathrm{VCO}_{2}\right.$ Ve) were measured breath-by-breath throughout all IET and IRT using wireless portable spirometry system "Oxycon mobile" (VIASYS Healthcare; California, USA). Prior to each test, the portable spirometry system was calibrated. The first and second (VT2) ventilation thresholds and $\mathrm{VO}_{2} \mathrm{max}$ were evaluated during the IRT on a LE $200 \mathrm{CE}$ treadmill (VIASYS, Germany). The average value of $\mathrm{VO}_{2}$ over the last $15 \mathrm{~s}$ of running was referred to as $\mathrm{VO}_{2} \max$.

Determination of ventilatory thresholds. VT1 ir VT2 were established according to the dependence of pulmonary ventilation as well as ventilation equivalents of oxygen $\left(\mathrm{Ve} / \mathrm{VO}_{2}\right)$ and carbon dioxide $\left(\mathrm{Ve} / \mathrm{VCO}_{2}\right)$ at the end of expiration on the work intensity performing IRT. VT1 was considered to be the intensity of the work load when the Ve increase accelerated for the first time, and the $\mathrm{Ve} / \mathrm{VO}_{2}$ started increasing without any changes in the $\mathrm{Ve} / \mathrm{VCO}_{2}$. VT2 was the intensity of the work load when the Ve increase accelerated for the second time, and the $\mathrm{Ve} / \mathrm{VCO}_{2}$ started increasing even faster with the increase in the $\mathrm{Ve} / \mathrm{VO}_{2}$.

Blood lactate concentration. Blood sample $(25 \mu \mathrm{l})$ for the measurement of blood lactate concentration ([La]) (Accutrend Portable Lactate Analyser, Roche, Germany) was taken from fingertips. 
Heart rate (HR) was continuously recorded every $5 \mathrm{~s}$ using a wireless Polar monitoring system (S810 Polar, Finland) during IET and IRT.

Anthropometric data. The subject's body composition components (body mass, free fat mass and fat mass) were measured using body composition analyser (Tanita, Japan).

EMG recording. Bipolar Ag-AgCI surface electrodes were used for surface electromyography (sEMG) recordings (silver bar electrodes, diameter $10 \mathrm{~mm}$, centre-to-centre distance $20 \mathrm{~mm}$ ) of right leg $m$. vastus lateralis (m. VL), $m$. vastus medialis (m. M) and $m$. gastrus lateralis (m. GL), m. gastrus medialis (m. GM) (DataLog type No. P3X8 USB, Biometrics Ltd, Gwent, Uk.). The skin at the electrode site was shaved and cleaned with alcohol wipes. To be sure that electrode was precisely at the same place for each IET, the electrode location was marked on the skin with an indelible marker. The electrodes were placed $2 / 3^{-1}$ on $\mathrm{m}$. VL and $80 \%$ way on $\mathrm{m}$. VM. Respectively $\mathrm{m}$. GL were placed $1 / 3^{-1}$ of the line between the head of the fibula and the heel and $\mathrm{m}$. GM on the most prominent bulge of the muscle. The ground electrode was positioned on the wrist of the left hand. The EMG parameters integrated electromyogram (iEMG), root mean square (RMS) of sEMG values were consistently taken during the course of IET.

Experimental protocol. The participant was familiarized with the research and signed informed consent to participate in it, she was tested under the same conditions. The participant performed three IRT on a treadmill - a control test, after 1 and 2 months of IET periods. The participant was included in a 2-month IET programme. The training frequency was 3 times per week, separated by 1-2 days of rest. The blood lactate concentration was measured on the $5^{\text {th }}$ and $20^{\text {th }}$ minutes of rest after IRT. $\mathrm{VO}_{2}, \mathrm{HR}$ parameters were measured during all tests (IRT, IET). The EMG parameters of right leg muscles and anthropometric parameters (body mass, free fat mass and fat mass) were measured every two weeks.

Statistical analysis. Descriptive data were expressed as mean values and standard deviations (SD). Comparisons between the four tests were made by nonparametric statistics and significant results were further analysed using Friedman ANOVA and Kendall's Concorde test. Statistical significance was accepted when $\mathrm{p}<0.05$.

\section{RESEARCH RESULTS}

Anthropometric data. After two months of IET the subject's body mass, fat mass $(\mathrm{kg})$, free fat mass (FFM) (kg) decreased respectively by 8.5, 17.2 and $3.5 \%$, compared to the first testing (Table 1).

Table 2 shows the effect of the two-month IET on the aerobic capacity that was measured during IRT. The maximal running speed, relative $\mathrm{VO}_{2} \max , \mathrm{HR} \max$ increased respectively by 7.0, 9.4 and $4.9 \%$ after IET compared to control testing. The alteration of aerobic capacity parameters at the VT1 and VT2 were different. The speed of running at VT1 and VT2 increased respectively by 8.1 and $10.2 \%$ after a two-month IET programme. HR at the VT1 increased by $7.8 \%$ and at the VT2 - by $6.3 \%$ after one month of IET, but it decreased respectively by 1.7 and $2.1 \%$ after two months of IET programme compared to middle testing.

The steady state of $\mathrm{VO}_{2}$ decreased significantly during the running sessions after two months IET (Figure 1), but the steady state of relative $\mathrm{VO}_{2}$ was unchanged (Figure 2). Heart rate significantly decreased after IET programmes compared to pretraining testing (Figure 3).

Table 2 shows the changes in EMG parameters during IET sessions every 2 weeks. The iEMG of $m$. vastus lateralis and $m$. vastus medialis during running intervals of training sessions significantly
Table 1. Changes in the
subject's anthropometric
parameters during IET
period

Note. $\downarrow-$ parameters' percentage decreased after two months of IET compared to Pre-training. BMI - the body mass index; TBW - the total body water.

\begin{tabular}{|l|c|c|c|c|c|c|}
\hline \multicolumn{1}{|c|}{ Parameters } & $\begin{array}{c}\text { Pre- } \\
\text { training }\end{array}$ & $\begin{array}{c}\text { After 2 } \\
\text { weeks }\end{array}$ & $\begin{array}{c}\text { After 4 } \\
\text { weeks }\end{array}$ & $\begin{array}{c}\text { After 6 } \\
\text { weeks }\end{array}$ & $\begin{array}{c}\text { After 8 } \\
\text { weeks }\end{array}$ & $\begin{array}{c}\text { Change of } \\
\text { percentages }\end{array}$ \\
\hline Weight, kg & 99.1 & 96.4 & 92.4 & 90.3 & 89.6 & $9.6 \downarrow$ \\
\hline BMI & 30.6 & 29.8 & 28.5 & 27.9 & 27.7 & $9.5 \downarrow$ \\
\hline Fat mass, \% & 44.7 & 43.4 & 41.8 & 40.8 & 40.9 & $8.5 \downarrow$ \\
\hline Fat mass, kg & 44.3 & 41.8 & 38.6 & 36.8 & 36.7 & $17.2 \downarrow$ \\
\hline Free fat mass, kg & 54.8 & 54.6 & 53.8 & 53.5 & 52.9 & $3.5 \downarrow$ \\
\hline TBW, kg & 40.1 & 40 & 39.4 & 39.2 & 38.7 & $3.5 \downarrow$ \\
\hline
\end{tabular}


increased after 6 and 8 weeks, and $m$. gastrus medialis significantly increased after 2, 6 and 8 weeks; $m$. gastrus lateralis significantly chances was determined after 4 weeks compeered with testing after 2 weeks IET. The following significant changes in RMS of EMG during the running intervals of the training session were observed: increase after 6,8 weeks of $m$. vastus lateralis and $m$. vastus medialis, after 2,6 and 8 weeks of m. gastrus medialis and decrease after 4, 6 and 8 weeks of $m$. gastrus lateralis.
$\mathrm{VO}_{2}$ kinetics parameters: baseline $\mathrm{VO}_{2}$; oxygen uptake amplitude $\left(\mathrm{AVO}_{2}\right)$ and oxygen uptake time constant $\left(\mathrm{tVO}_{2}\right)$ are given in Figure 4. The baseline $\mathrm{VO}_{2}$ (Figure 4A) significantly decreased after 2-8 weeks of IET compeered to pre-training testing. The $\mathrm{AVO}_{2}$ (Figure $4 \mathrm{~B}$ ) significantly increased after 5 weeks, but it decreased after 7-8 weeks of IET compared to pre-training testing. There were no significant differences in $\mathrm{tVO}_{2}$ under different testing conditions (Figure $4 \mathrm{C}$ ).

\begin{tabular}{|c|c|c|c|}
\hline & Control testing & After one month & After two months \\
\hline \multicolumn{4}{|c|}{ Data at the first ventilation threshold (VT1) } \\
\hline Running speed at VT1, $\mathrm{km} / \mathrm{h}^{-1}$ & 8.7 & 9.2 & 9.4 \\
\hline Heart rate at VT1, beats $/ \mathrm{min}^{-1}$ & 165 & 178 & 175 \\
\hline $\mathrm{VO}_{2}$ at $\mathrm{VT} 1,1 / \mathrm{min}^{-1}$ & 2.778 & 2.820 & 2.594 \\
\hline \multicolumn{4}{|c|}{ Data at the second ventilation threshold (VT2) } \\
\hline Running speed at VT2, $\mathrm{km} / \mathrm{h}^{-1}$ & 10.8 & 11.7 & 11.9 \\
\hline Heart rate at VT2, beats $/ \mathrm{min}^{-1}$ & 176 & 187 & 183 \\
\hline $\mathrm{VO}_{2}$ at $\mathrm{VT} 2,1 / \mathrm{min}^{-1}$ & 3.233 & 3.356 & 3.292 \\
\hline \multicolumn{4}{|c|}{ Maximal data } \\
\hline Maximal running speed, $\mathrm{km} / \mathrm{h}^{-1}$ & 12.8 & 13.5 & 13.7 \\
\hline Absolute $\mathrm{VO}_{2} \max , 1 / \mathrm{min}^{-1}$ & 3.683 & 3.731 & 3.644 \\
\hline Relative $\mathrm{VO}_{2} \max , \mathrm{ml} / \mathrm{kg} / \mathrm{min}^{-1}$ & 37.2 & 40.4 & 40.7 \\
\hline Heart rate $\max$, beats $/ \mathrm{min}^{-1}$ & 184 & 192 & 193 \\
\hline TDmax, 1 & 2.984 & 2.624 & 2.758 \\
\hline VEmax, $1 / \min ^{-1}$ & 137.3 & 136.0 & 136.0 \\
\hline
\end{tabular}

Table 2. Aerobic capacity parameters during incremental running test

Note. VT1 - first ventilation threshold; $\mathrm{VO}_{2}$ - oxygen uptake; VT2 - second ventilation threshold; $\mathrm{VO}_{2} \mathrm{max}$ - maximal oxygen uptake; TD - tidal volume; VEmax - maximal ventilation.

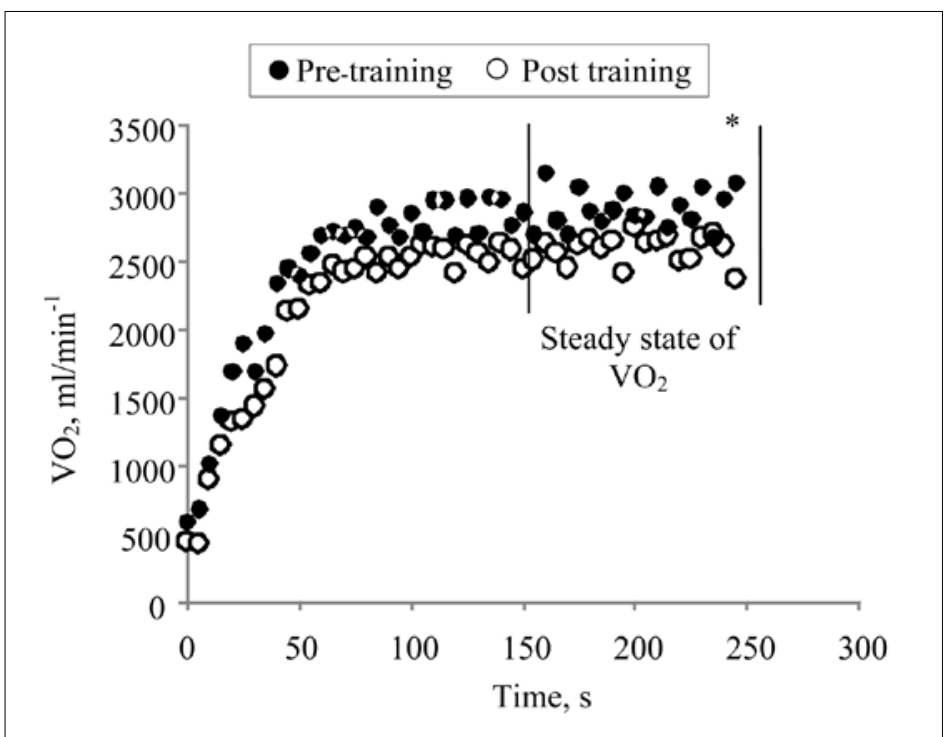

Figure 1. Oxygen uptake average during 8 repetitions of 4 min running sessions before $(\bullet)$ and after $(\circ)$ the training period

Note. ${ }^{*}$ - significant difference compared to pre-training; $\mathrm{VO}_{2}$ - oxygen uptake. 
Figure 2. Relative oxygen uptake average during 8 repetitions of 4 min running sessions before $(\bullet)$ and after $(\circ)$ the training period

Note. $\mathrm{VO}_{2}$ - oxygen uptake.

Figure 3. Heart rate $5 \mathrm{~s}$ interval average during 8 repetitions of 4 min running sessions before $(\bullet)$ and after $(\circ)$ the training period

Note. * - significant difference compared to pre-training.
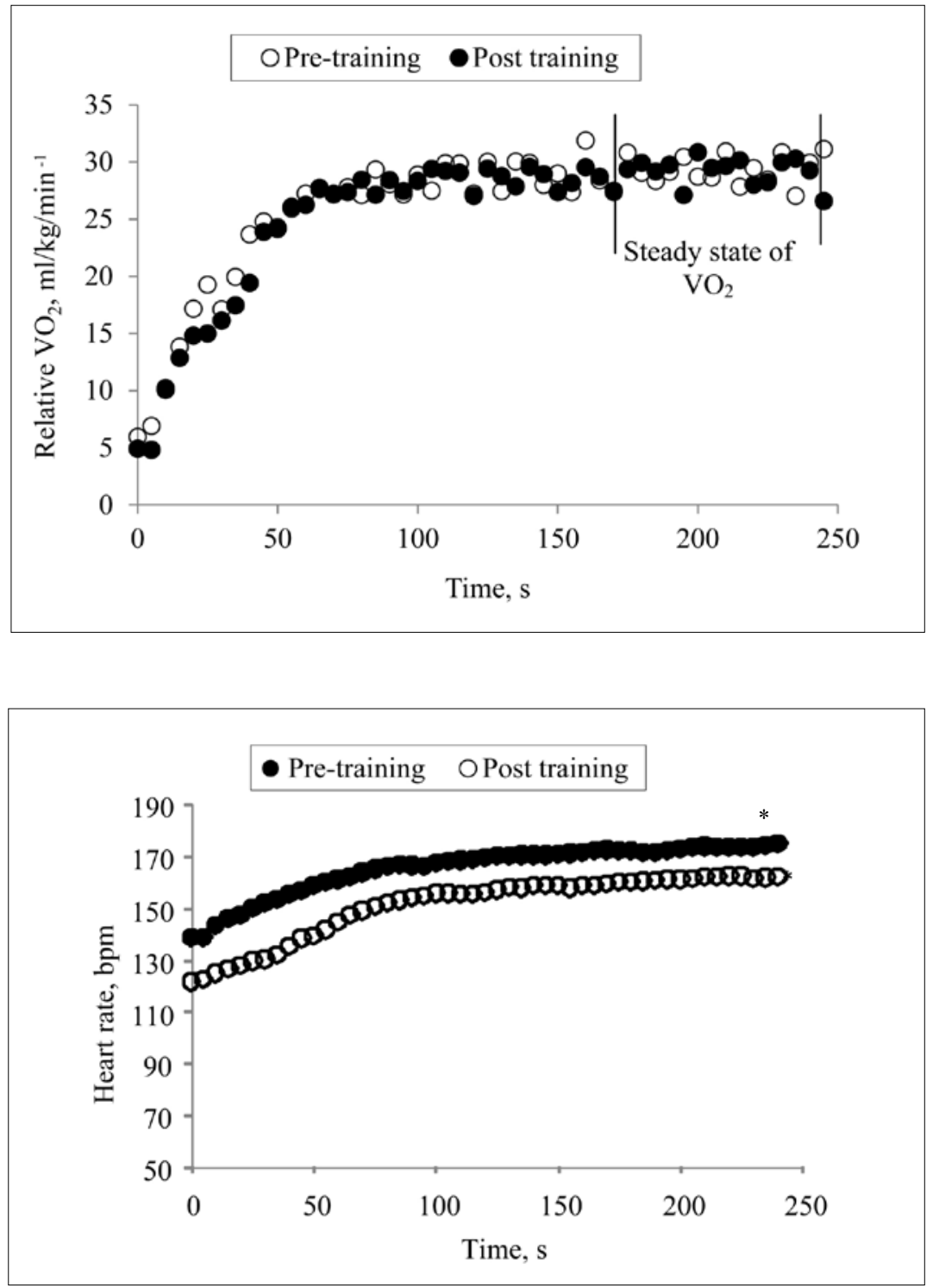

Table 3. The EMG parameters during interval endurance training every two weeks

\begin{tabular}{|c|c|c|c|c|c|c|c|c|c|c|}
\hline \multirow[b]{2}{*}{ Muscles } & \multicolumn{5}{|c|}{ iEMG, $\mathrm{mV} / \mathrm{s}^{-1}$} & \multicolumn{5}{|c|}{ RMS, mV } \\
\hline & 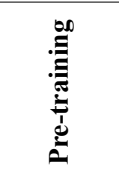 & 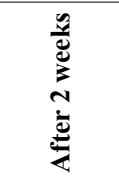 & 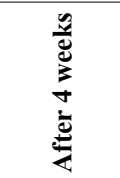 & 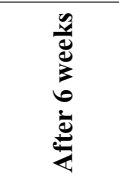 & 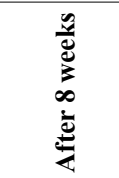 & 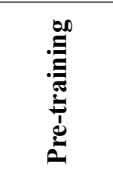 & 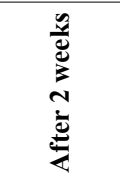 & 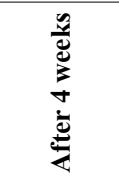 & 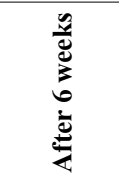 & 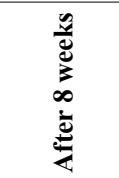 \\
\hline $\begin{array}{l}\text { Vastus } \\
\text { lateralis }\end{array}$ & $\begin{array}{c}0.021 \\
(0.001)\end{array}$ & $\begin{array}{c}0.021 \\
(0.001)\end{array}$ & $\begin{array}{c}0.021 \\
(0.001)\end{array}$ & $\begin{array}{c}0.026 \\
(0.001)^{*}\end{array}$ & $\begin{array}{c}0.028 \\
(0.001)^{*}\end{array}$ & $\begin{array}{c}0.079 \\
(0.004)\end{array}$ & $\begin{array}{c}0.080 \\
(0.005)\end{array}$ & $\begin{array}{c}0.078 \\
(0.003)\end{array}$ & $\begin{array}{c}0.094 \\
(0.006)^{*}\end{array}$ & $\begin{array}{c}0.092 \\
(0.013)^{*}\end{array}$ \\
\hline $\begin{array}{l}\text { Vastus } \\
\text { medialis }\end{array}$ & $\begin{array}{c}0.028 \\
(0.001)\end{array}$ & $\begin{array}{c}0.027 \\
(0.001)\end{array}$ & $\begin{array}{c}0.028 \\
(0.001)\end{array}$ & $\begin{array}{c}0.034 \\
(0.001)^{*}\end{array}$ & $\begin{array}{c}0.042 \\
(0.005)^{*}\end{array}$ & $\begin{array}{c}0.107 \\
(0.007)\end{array}$ & $\begin{array}{c}0.106 \\
(0.008)\end{array}$ & $\begin{array}{c}0.099 \\
(0.003)\end{array}$ & $\begin{array}{c}0.124 \\
(0.006)^{*}\end{array}$ & $\begin{array}{c}0.137 \\
(0.013)^{*}\end{array}$ \\
\hline $\begin{array}{l}\text { Gastrus } \\
\text { lateralis }\end{array}$ & $\begin{array}{c}0.026 \\
(0.035)\end{array}$ & $\begin{array}{c}0.027 \\
(0.001)\end{array}$ & $\begin{array}{c}0.023 \\
(0.001)^{\#}\end{array}$ & $\begin{array}{c}0.025 \\
(0.002)\end{array}$ & $\begin{array}{c}0.026 \\
(0.005)\end{array}$ & $\begin{array}{c}0.095 \\
(0.005)\end{array}$ & $\begin{array}{c}0.097 \\
(0.002)\end{array}$ & $\begin{array}{c}0.082 \\
(0.005)^{*}\end{array}$ & $\begin{array}{c}0.087 \\
(0.005)^{*}\end{array}$ & $\begin{array}{c}0.079 \\
(0.013)^{*}\end{array}$ \\
\hline $\begin{array}{l}\text { Gastrus } \\
\text { medialis }\end{array}$ & $\begin{array}{c}0.034 \\
(0.001)\end{array}$ & $\begin{array}{c}0.040 \\
(0.001)^{*}\end{array}$ & $\begin{array}{c}0.036 \\
(0.001)\end{array}$ & $\begin{array}{c}0.041 \\
(0.001)^{*}\end{array}$ & $\begin{array}{c}0.051 \\
(0.001)^{*}\end{array}$ & $\begin{array}{c}0.141 \\
(0.006)\end{array}$ & $\begin{array}{c}0.158 \\
(0.008)^{*}\end{array}$ & $\begin{array}{c}0.141 \\
(0.007)^{*}\end{array}$ & $\begin{array}{c}0.159 \\
(0.005)^{*}\end{array}$ & $\begin{array}{c}0.163 \\
(0.021)^{*}\end{array}$ \\
\hline
\end{tabular}

Note. Values presented are means \pm SD. Integrate electromyogram values (iEMG); Root mean square values (RMS). * - significant difference compared to pre-training; \#-significant difference compared to 2 weeks of IET. 


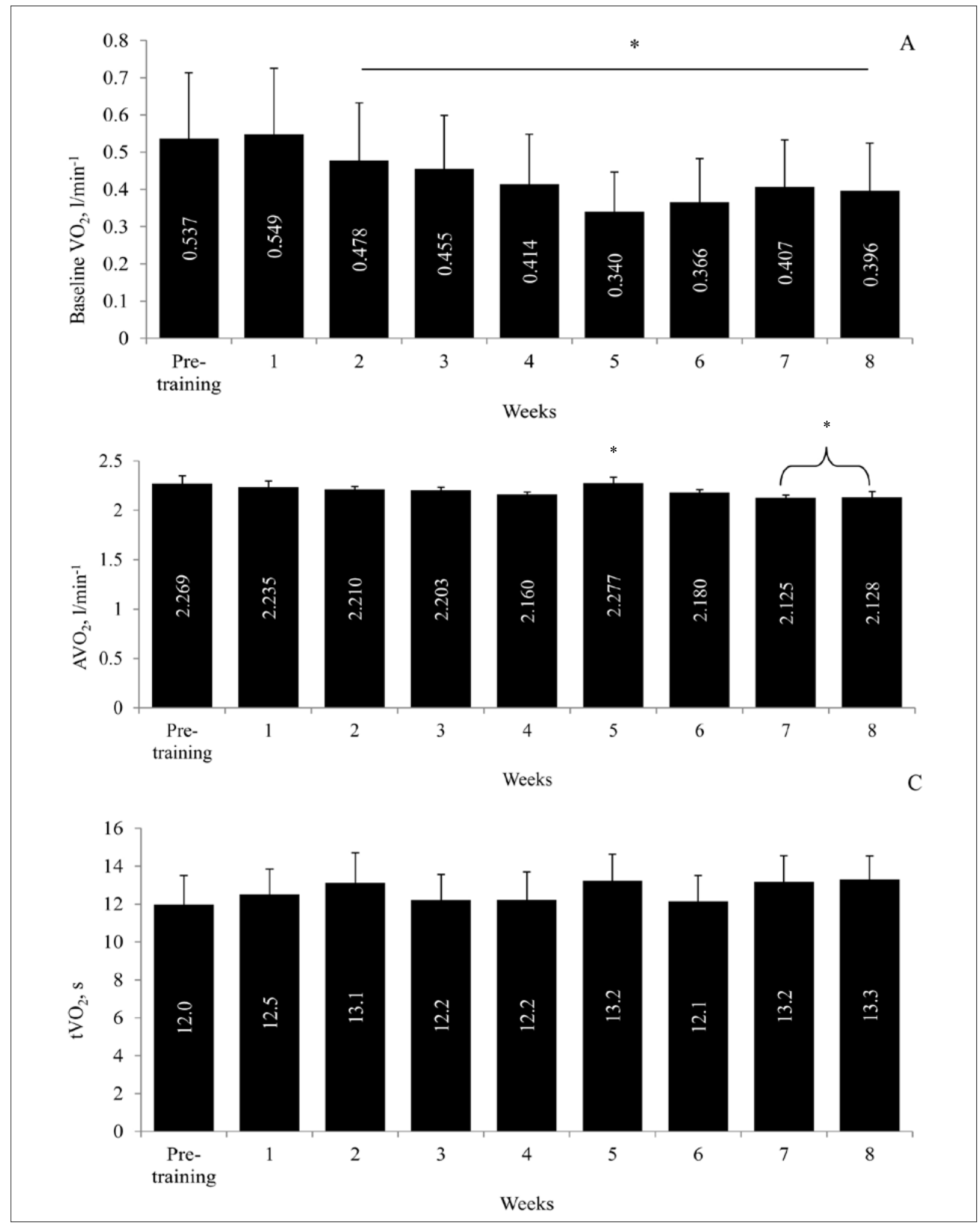

Note. Oxygen uptake amplitude $\left(\mathrm{AVO}_{2}\right)$ and time constant of oxygen uptake $\left(\mathrm{tVO}_{2}\right) ;{ }^{*}$ - significant difference compared to pre-training.

Figure 4. Baseline oxygen uptake (A), amplitude of oxygen uptake (B) and time constant of oxygen uptake (C) mean values every week during interval endurance training 


\section{DISCUSSION}

The main focus of this study was to determine the effects of IET on cardiorespiratory system parameters in sedentary obesity subject. We demonstrated that the two months of IET were equally effective in improving anthropometric, aerobic capacity and EMG parameters.

Different training programmes have various effects on anthropometric parameters. I. E. Schjerve and colleagues (2008) determined that aerobic training regimens had significant effect on body weight; moreover, high intensity sprint and continuous endurance training improved metabolic parameters, BMI and aerobic capacity in children. It was established that aerobic interval training and continuous moderate training led to slight reduction of 3 and 4\%, respectively, in body weight (Tjonna et al., 2008). In our study we established that IET had an important effect on the anthropometric parameters (weight, BMI, fat mass, free fat mass). However, the optimal type of training capable of eliciting the most important health benefits and improve the aerobic capacity in untrained people remains debatable. A. Corte de Araujo et al. (2012) affirmed that endurance and sprint training improved aerobic capacity $\left(\mathrm{VO}_{2} \mathrm{max}\right.$, time to exhaustion) in youth. B. R. McKay and colleagues (2009) suggested that endurance training failed to increase the absolute $\mathrm{VO}_{2}$ max, although the relative $\mathrm{VO}_{2}$ max increased by a small, but significant, amount: $2-3 \mathrm{ml} / \mathrm{kg}^{-1} / \mathrm{min}^{-1}$. In healthy populations, high intensity training has been shown to improve $\mathrm{VO}_{2} \max$ (McManus et al., 2005), maximal velocity in the incremental test, high-intensity intermittent performance, peak and submaximal oxygen pulse, and resting pulmonary function and ventilatory response to exercise. Our results are consistent with previous studies; we also determined decreases in relative $\mathrm{VO}_{2} \max$ and time to exhaustion after two months of IET. These changes could be related with a decrease in body mass (McKay et al., 2009). We mentioned earlier that high intensity aerobic interval training had a higher effect on $\mathrm{VO}_{2} \max$ than moderate intensity training, but our results showed that IET also improved $\mathrm{VO}_{2}$ max after 2 months. However, several short training studies (i. e. 1-3 weeks), demonstrated an increase in endurance performance and oxidative capacity without significant increases in $\mathrm{VO}_{2} \max$.

In a previous study, S. M. Phillips and colleagues (1995) reported that $\mathrm{VO}_{2}$ kinetics became faster only after 4 days of continuous endurance training. The phase $\mathrm{II}_{\mathrm{t}} \mathrm{VO}_{2}$ was reduced by $\sim 22 \%$ after 4 days of training (i. e. from 37 to $29 \mathrm{~s}$ ), which was similar to the $\sim 30 \%$ high intensity training and $\sim 17 \%$ endurance training in the present study. However, in the present study, there was a significant reduction in $\mathrm{V}_{\mathrm{t}} \mathrm{O}_{2}$ after only 2 training days $(\sim 17-20 \%$ for both high intensity and endurance training. Our results differ from previous studies, we did not determine significant decrease in ${ }_{\mathrm{t}} \mathrm{VO}_{2}$ after interval endurance training intervention, though baseline $\mathrm{VO}_{2}$ decreased after 2 weeks and the amplitude of $\mathrm{VO}_{2}-$ after 7-8 weeks of IET. H. Carter and colleagues (2000) determined that high intensity endurance training program had no effect on the kinetics of the $\mathrm{VO}_{2}$ response to moderate exercise but it became faster during intense exercise. This tends to support the idea that $\mathrm{VO}_{2}$ kinetics speed depends on oxygen delivery and muscle mitochondrial density with training. Another explanation is that $\mathrm{VO}_{2}$ depends on endurance training intensity. It should be higher than $90 \%$ of VT1. Nonetheless this IET intensity is enough to improve aerobic capacity, anthropometric parameters and has effect on muscle electrical activity.

Many researchers explain the increase in EMG amplitude and iEMG as evidence of additional recruitment of motor units in order to compensate the force loss of working muscle fibres (Gandevia, 2001). EMG studies with surface electrodes during dynamic muscle contractions are rarer than those under static conditions (Enoka, Stuart, 1992). There is much disagreement about the effect of fatigue on the EMG parameters during dynamic exercise. EMG activity has been studied in conjunction with investigations of the $\mathrm{VO}_{2}$ slow component to determine whether there is an increase in iEMG or in MPF (Perrey et al., 2001). The increase in iEMG might reflect greater total muscle fibre recruitment (Shinohara, Moritani, 1992) as fibre fatigue. During exercise, such as running, that involves eccentric and concentric muscle actions, it appears that the magnitude of the $\mathrm{VO}_{2}$ slow component is reduced when the proportion of concentric exercise is reduced (Jones, McConnell, 1998). J. Mizrahi and colleagues (2000) determined that during 30 min running on treadmill the load was above anaerobic thresholds. In the tibialis anterior the average iEMG and the 
MPF significantly decreased from the beginning to the end of running. In the gastrocnemius iEMG did not change, while MPF increased during the course of running. In the present study, iEMG and RMS significantly increased after six weeks during the IET running period in all muscles except for $m$. gastrus lateralis. The iEMG and RMS of $m$. gastrus lateralis significantly decreased respectively after four, six and eight weeks of IET.

\section{CONCLUSION AND PERSPECTIVES}

In conclusion, two months of interval endurance training has a positive effect on anthropometric parameters and aerobic capacity, though $\mathrm{VO}_{2}$ kinetics parameters have not changed considerably. This training also influences muscle activity, iEMG and RMS significantly increased after four, six and eight weeks.

\section{REFERENCES}

Burgomaster, K. A., Howarth, K. R., Phillips, S. M. et al. (2008). Similar metabolic adaptations during exercise after low volume sprint interval and traditional endurance training in humans. Physiology Journal, 586, $151-160$

Carter, H., Jones, A. M., Barstow, T. J. et al. (2000). Effect of endurance training on oxygen uptake kinetics during treadmill running. European Journal of Applied Physiology, 89, 1744-1752.

Corte de Araujo, A. C., Roschel, H., Picanço, A. R. et al. (2012). Similar health benefits of endurance and high-intensity interval training in obese children. Public Library of Science, 7 (8), 427-447.

Donnelly, J. E., Blair, S. N., Jakicic, J. M. et al. (2009). American College of Sports Medicine Position Stand. Appropriate physical activity intervention strategies for weight loss and prevention of weight regain for adults. Medicine and Science in Sports and Exercise, 41, 459-471.

Enoka, R. M., Stuart, D. G. (1992). Neurobiology of muscle fatigue. Journal of Applied Physiology, 72 (5), 1631-1648.

Farina, D., Merletti, R., Enoka, R. M. (2004). The extraction of neural strategies from the surface EMG. European Journal of Applied Physiology, 96, 14861495.

Gandevia, S. C. (2001). Spinal and supraspinal factors in human muscle fatigue. Physiological Reviews, 81, $1725-1789$.

Gibala, M. J., Little, J. P., Wilkin, V. E. M. et al. (2006). Short-term sprint interval versus traditional endurance training: Similar initial adaptations in human skeletal muscle and exercise performance. Physiology Journal, 575, 901-911.

Jones, A. M., McConnell, A. M. (1999). Effect of exercise modality on oxygen uptake kinetics during heavy exercise. European Journal of Applied Physiology, 80, 213-219.

Krustrup, P., Soderlund, K., Mohr. M., Bangsbo, J. (2004). The slow component of oxygen uptake during intense, submaximal exercise in man is associated with additional fiber recruitment. Pflügers Archiv European Journal of Physiology, 447, 855-866.

McInnis, K. J., Franklin, B. A., Rippe, J. M. (2003). Counselling for physical activity in overweight and obese patients. American Family Physician, 67, 12491256.

McKay, B. R., Paterson, D. H., Kowalchuk, J. M. (2009). Effect of short-term high-intensity interval training vs. continuous training on $\mathrm{O}_{2}$ uptake kinetics, muscle deoxygenation, and exercise performance. European Journal of Applied Physiology, 107, 128-138.

McManus, A. M., Cheng, C. H., Leung, M. P., Yung, T. C., Macfarlane, D. J. (2005). Improving aerobic power in primary school boys: A comparison of continuous and interval training. International Journal of Sports Medicine, 26, 781-786.

Mizrahi, J., Verbitsky, O., Isakov, E. (2000). Fatiguerelated loading imbalance on the shank in running: A possible factor in stress fractures. Annals of Biomedical Engineering, 4, 463-469.

Perrey, S., Tschakovsky, M. E., Hughson, R. L. (2001). Muscle chemoreflex elevates muscle blood flow and $\mathrm{O}_{2}$ uptake at exercise onset in nonischemic human forearm. Journal of Applied Physiology, 91 (5), 2010-2016.

Phillips, S. M., Green, H. J., MacDonald, M. J., Hughson, R. L. (1995). Progressive effect of endurance training on $\mathrm{VO}_{2}$ kinetics at the onset of submaximal exercise. European Journal of Applied Physiology, 79, 1914-1920.

Rakobowchuk, M., Tanguay, S., Burgomaster, K. A. et al. (2008). Sprint interval and traditional endurance training induce similar improvements in peripheral arterial stiffness and flow-mediated dilation in healthy humans. American Journal of Physiology. Regulatory, Integrative and Comparative Physiology Journal, 295, 236-242.

Schjerve, I. E., Gjertrud, A., Tyldum, A. E. et al. (2008). Both aerobic endurance and strength training programmes improve cardiovascular health in obese adults. Clinical Science, 115, 283-293.

Shinohara, M., Moritani, T. (1992). Increase in neuromuscular activity and oxygen uptake during heavy exercise. Annals of Physiological Anthropology, 11, 257-262.

Tjonna, A. E., Lee, S. J., Rognmo, O. (2008). Aerobic interval training versus continuous moderate exercise as a treatment for the metabolic syndrome: A pilot study. Circulation Journal, 118, 346-354. 


\title{
DVIEJŲ MĖNĖSIŲ VIDUTINIO INTENSYVUMO INTERVALINIŲ IŠTVERMĖS PRATYBŲ POVEIKIS DEGUONIES KINETINĖMS YPATYBËMS, AEROBINIAM PAJE்GUMUI IR EMG RODIKLIAMS (ATVEJO TYRIMAS)
}

\author{
Sandra Raubaitė, Neringa Baranauskienė, Arvydas Stasiulis \\ Lietuvos sporto univeritetas, Kaunas, Lietuva
}

\begin{abstract}
SANTRAUKA
Tyrimo pagrindimas ir hipotezè. Vidutinio ar mažo nenutrūkstamo intensyvumo ištvermès krūvis pagerina nesportuojančių asmenų kūno kompozicijos, aerobinio pajëgumo ar kitus su sveikata susijusius rodiklius. Visgi nèra atlikta tyrimu, koki poveiki dviejų mėnesiu vidutinio intensyvumo intervalinès ištvermès pratybos (IIT) turètų aerobiniam pajègumui, deguonies kinetinèms ypatybèms $\left(\mathrm{VO}_{2}\right)$, antropometriniams rodikliams ir raumenu aktyvumui.

Tikslas - i̇vertinti dviejų mėnesiu IIT poveiki aerobiniam pajëgumui, deguonies kinetinėms ypatybėms, EMG ir kūno kompozicijos rodikliams.

Metodai. Buvo tiriama 26 metu nesportuojanti, turinti antsvorio moteris (ūgis $-180 \mathrm{~cm}$; svoris $-99,1 \mathrm{~kg}$; $\mathrm{VO}_{2} \max -37,2 \mathrm{ml} / \mathrm{kg} / \mathrm{min}$ ). Ji buvo ịtraukta ị dviejų mėnesių IIT ciklą. Tiriamoji turejjo trejas pratybas per savaitę, tarp kuriu būdavo viena arba dvi dienos poilsio. Pratybų intensyvumas $90 \%$ nuo pirmo ventiliacinio slenksčio. Slenksčiai buvo nustatomi atliekant nuosekliai didinamą krūvị iki visiško nuovargio bėgtakiu LE 200 (VIASYS, Vokietija).

Rezultatai. Tiriamosios kūno mase po dviejų mėnesių IIT sumažèjo $10 \%$, greitis ties pirmu ir antru ventiliaciniu slenksčiu padidèjo atitinkamai 8,1 ir 10,2\%. Šrdies susitraukimu dažnis $(165.9 \mathrm{tv} . / \mathrm{min})$ ir absoliutus $\mathrm{VO}_{2}$ ( $2.583 \mathrm{l} / \mathrm{min})$, užfiksuotas pirmos IIT metu, atitinkamai reikšmingai sumažejo po pratybų ciklo (150.4 tv./min; $2.285 \mathrm{l} / \mathrm{min}$ ). Reikšmingi EMG pokyčiai nustatyti po keturių šešių ir aštuonių savaičių IIT pratybų šiuose raumenyse: šlaunies šoninio ir vidinio plačiojo, blauzdos dvilypio raumens vidinès ir šoninès galvos.

Aptarimas ir išvados. Dviejų mėnesių trukmès IIT reikšmingai paveikia aerobinį pajëgumą, kūno kompoziciją ir EMG rodiklius, tačiau tokio intensyvumo pratybos mažiau veikia deguonies kinetines ypatybes.
\end{abstract}

Raktažodžiai: ventiliaciniai slenksčiai, EMG amplitudès vidutinè kvadratinė reikšmè, maksimalusis deguonies suvartojimas.

Gauta 2013 m. lapkričio 3 d.

Received on November 3, 2013 